\title{
Playing with tension: national charisma and disgrace at Euro2012
}

Alex Law

This is an Accepted Manuscript of an article published by Taylor \& Francis in Soccer \& Society on 29th October 2013, available online: http://www.tandfonline.com/10.1080/14660970.2013.849187 


\title{
Playing with Tension: National Charisma and Disgrace at Euro2012 ${ }^{1}$
}

\author{
Alex Law \\ Division of Sociology, University of Abertay, Dundee, DD1 1HG \\ a.law@abertay.ac.uk
}

Soccer and Society special issue, 'Exploring the cultural, ideological and economic legacies of Euro2012':

\begin{abstract}
By the time of Euro 2012, deepening tensions of nationalism and internal social struggles were developing across Europe in worsening conditions of systemic crisis. The official football ideology of UEFA conceives Euro2012 as a civilising platform for mutual respect and brotherhood between competing nations. In contrast, what I call Hyper-Critical Theory conceives of football competitions like Euro2012 as part of a de-civilising 'sports mode of production' that necessarily produces crisis conditions, alienation and violence on a mass scale, fostering nationalism, militarism and racism. Between these polar perspectives, the figurational sociology of sport associated with Norbert Elias proposes that major international football competitions like Euro2012 creates and dissipates contingent tensions of 'group charisma' and 'group disgrace'. Study of Euronews 'post-national' coverage of Euro2012 allows their explanatory adequacy to be compared. In a competition structure like the Euros no social group - players, officials, media or fans - is able to disregard entirely the field capabilities of the 'best minority of 11 ' in the serious game of exemplifying the group charisma of nations.
\end{abstract}




\section{Playing with Tension: National Charisma and Disgrace at Euro2012}

\section{Introduction}

Suitably ambiguous, the official slogan for Euro 2012 was 'Creating History Together'. For UEFA (Union des Associations Européennes de Football) this reflected the fact that the tournament was being held for the first time in post-Soviet central and eastern Europe, Poland and Ukraine. The 'history' referred to is understood to be simultaneously football history and European history. ${ }^{2}$ Selfconsciously 'historical' the competition slogan expressed something of the tension between the dual civilising missions of football and the European state formation process. Since the 1940s core European nations were released from a revenge cycle of violence founded on the national humiliation and collective shame of total war, mass atrocities, occupation, defeat and declining state power. ${ }^{3}$ Yet, with a weak European public sphere and with no Europe-wide state form to concentrate and centralise the means of violence, Europe remains dangerously fractured between rival states.

Euro 2012 took place amidst collective fears and insecurities brought on by economic and political crises. Historically, conditions of institutional crisis generate and heighten political, ethnic and nationalist conflicts and anxieties. The crisis in Europe operates through an ideological prism of irresponsible states and nationalist stereotypes. ${ }^{4}$ States covered by the derogatory acronym 'PIGS' (Portugal, Ireland, Greece, Spain) are charged as incompetent and parasitic, supporting a supposedly indulgent national culture with surplus revenue generated by core European institutions. Far from the ideal of continental unity enshrined in the sports ideology of the European Championship, the European state system was rent with internal crisis.

In some ways football functions as an intermediary conscience collective in the absence of a European public sphere. ${ }^{5}$ Formed in 1954 with 25 members, the number of national football associations belonging to UEFA grew rapidly in post-Soviet Europe to fifty-three by Euro 2012. Typically, national football associations are more or less congruent with the nation-state, with the four national football associations of the UK - England, Scotland, Wales and Northern Ireland - something of an exceptional case. Competitive football and competitive nationalism are tethered together. While there may be some evidence of a shallow European identity at 
previous European Championships, this remains subordinate to the reproduction of nationalist perceptual frames. ${ }^{6}$ The football field is never an autonomous zone, set free from other fields of power. International football is always a field of tensions. For instance, around the same time that 'little' Denmark rejected, at least initially, the Maastricht Treaty as reflecting over-weaning German power, the Danish defeat of Germany in the Euro 1992 final stimulated a spasm of anti-German nationalism. ${ }^{7}$ Similarly, the violent reaction of Zinedine Zidane in the 2006 World Cup final is inexplicable without an understanding of 'games within games', where race, gender and nationality intersect as antagonistic social fields on the football field. ${ }^{8}$

Analysis of Euronews coverage of Euro2012 reveals something of the tensions between competitive football and competitive nationalism in conditions of the European state system in crisis. Broadcasting simultaneously in eleven languages, ${ }^{9}$ Euronews is one of the few venues for a European public sphere. ${ }^{10}$ Its founding ideology aims to produce 'European news for Europeans'. ${ }^{11}$ As the semi-official news media of Europeanism, Euronews presents certain advantages for gauging the extent to which tensions between nations and states within Europe are channeled by 'the other Euro' of inter-national football. For one thing, Euronews covered Euro2012 from a trans-national perspective rather than the banal nationalism that routinely frames news and sports media. ${ }^{12}$ For this study a corpus was assembled of all Euronews broadcasts in English that mentioned Euro 2012 in any context - sporting, economic, political, cultural - in the weeks before, during and after the tournament from May to July 2012. Under the deal struck between UEFA and the European Broadcasting Union (EBU), Euronews did not have broadcasting rights for the tournament. ${ }^{13}$ Instead, Euronews bulletins relied on analysis of still photography and computer graphics of play. This produced a more detached and analytical effect than live action replays of dramatic moments. As much emphasis was given to events outside the stadium as coverage of on-field play, giving prominence to the interactions between fans of different nationalities.

If Euronews coverage falls somewhat short of forming a European public sphere founded on factual impartiality it nonetheless expresses some of the emergent tensions and dynamics between opposing national groups in a supposedly depoliticized international sports context. While Euronews cannot be considered a 
neutral arbiter between states, it shares with UEFA an ideological commitment to the civilizing function of globalised Europeanism. It also provides empirical representations for examining the sociology of emotional, political and economic tensions generated by international football. At the polar extreme of official UEFA football ideology, what I will call 'Hyper-Critical Theory' denies that football can perform any civilising function; if anything football deepens the de-civilising violence of contemporary capitalism. Between official sports ideology and Hyper-Critical Theory, the figurational sociology of sport pioneered by Norbert Elias and Eric Dunning more dialectically identifies international football as a serious but contained game that generates and alleviates heightened emotional and bodily tensions in exciting but generally peaceful ways.

\section{Three Perspectives on Football}

For official sports ideology football creates a civilising space for national groups to make contact with and to recognise each other below the level of formal political structures. Since the 1984 European Championship in France, fans of national teams attend the Euros in increased numbers, resulting in generally peaceful contact with each other, although fan hooliganism remained a constant concern for authorities. ${ }^{14}$ As fan mobility increased and trans-national media audiences for the competition grew, UEFA aligned itself explicitly with the European Union ideal of 'unity in diversity'. UEFA identifies with the civilising effects of the European state system that pulled Europe out of wartime devastation and national hatreds into continental prosperity and peace.

UEFA's Fair Play code attempts to moderate the conduct of players, officials and fans under an ideology of 'the sporting spirit'. As UEFA state: 'The objective of activities in favour of fair play is to foster a sporting spirit, as well as the sporting behaviour of players, team officials and spectators, thereby increasing the enjoyment of all those involved in the game'. ${ }^{15}$ Officials are required to actively moderate any excesses of fans and players: 'Positive and negative aspects of the behaviour of team officials should be assessed; e.g. whether they calm or provoke angry players or fans, how they accept the referee's decisions, etc'. ${ }^{16}$ For their part, players should control their emotions, even when decisions are unfairly given against them: 'A positive attitude towards the referees should be rewarded by high marks, including the acceptance of 
doubtful decisions without protest' ${ }^{17}$ Although very few fans will have ever read official regulations they are expected by UEFA to create an exciting atmosphere but were also instructed to 'respect' certain boundaries of behaviour and avoid gratuitously offensive, threatening or violent behaviour towards opposing fans, players or officials.

The crowd is considered to be a natural component of a football game. The support of the fans may contribute to the success of their team. The crowd is not expected to watch the game in silence. Encouragement of teams by shouting, singing, etc. may have a positive influence on the atmosphere, in accordance with the spirit of fair play. The spectators are, however, expected to respect the opposing team and the referee. They should appreciate the performance of the opposition, even if they emerge as the winners. They must in no way intimidate or frighten the opposing team, the referee or opposing supporters. ${ }^{18}$

UEFA freights civilised sporting conduct through the injunction to observe an affirmative football ideology that at all times respects authority. In so doing, official football ideology consolidates the nationalist self-perception of fans, national associations and media alike.

In stark contrast to official sports ideology, for Hyper-Critical Theory competitions like Euro 2012 only serve to exacerbate violent rivalries between nations. HyperCritical Theory derives principally from 'the Frankfurt School' of Max Horkheimer, Theodor Adorno, Herbert Marcuse and Jurgen Habermas among others, alongside related theorists like Siegfried Kracauer and Walter Benjamin. ${ }^{19}$ In the exercise of disciplined obedience to rules sport infantilises and enslaves adult males in purposeless displays of pseudo-military aggression, producing the stupefying effect of what Adorno called 'meaningless activity with a specious seriousness and significance'. ${ }^{20}$ From these premises, a more polemical Hyper-Critical Theory of sport emerged, represented by Jean-Marie Brohm, Bero Rigauer, Gerhard Vinnai and Marc Perelman. For Hyper-Critical Theory, forced bodily repetition in professional football reveals a brutalising form of mass suffering raised to the level of a global spectacle, a self-mutilating training and compensation for the loss of free and spontaneous play. 
Football staves off boredom and monotony only by reintroducing it in a more compulsive, violent form. Like capitalist work relations, it dulls free play, moral worth and rational thought. ${ }^{21}$ Spectators at Euro2012 were reduced to a geometrically undifferentiated stadium mass, emotionally regulated by the psycho-acoustics of the crowd's voice, the playing of national anthems, team presentations, flag waving, as well as the wider ideological function of media communications in news and sports programming. Subject to a field of heightened sound and vision critical thought seems impossible and violence routine: 'The violence of seeing is constantly activated by the violence of successive shocks arousing extraordinary emotions; seeing means literally accepting violence and internalizing it as one's vector of inclination; seeing means being in permanent shock without being aware of it'. ${ }^{22}$

Given football's predisposition towards violence identified by Hyper-Critical Theory, Euro2012 appeared perfectly poised to generate large-scale brutality and sadism. Through its fusion with mass media, football relentlessly promotes national chauvinism, racism and xenophobia. As the 'sport mode of production' saturates everyday life competitive nationalism and competitive football increasingly define each other. Perelman advances a categorical critique of the true 'essence' of sport as endemic violence. In a society bereft of collective projects, 'sport flattens everything as it passes and becomes the sole project of a society without projects' ${ }^{23}$ Humiliated by the lash of globalization, international football allows for the compensatory release of nationalist aggression:

Sporting nationalism contributes to the unrestrained behaviour of overheated supporters and shares in the generalized violence of which sport is the most visible public manifestation. Everywhere can be found the worship of strength, contempt for weakness, chauvinism, racism, xenophobia, anti-Semitism, homophobia, verbal and physical violence inside and outside stadiums, brutality on every ground. ${ }^{24}$

Old ideals about fair play, sportsmanship and self-realisation give way to demands for competitive victory at all costs. Team discipline and one-sided specialisation recalls military discipline, unthinking and unfeeling obedience and neurotic self-abnegation for the national cause. Professional footballers are 'happy in their suffering and suffer 
for their happiness' ${ }^{25}$ Collective narcissism and violent domination fantasies are given free-rein: 'All the values of the capitalist jungle are played out in sport: virility, sexual athleticism, physical dominance, the superman, muscle worship, fascistic male chauvinism, racism, sexism etc. ${ }^{, 26}$ Large screen technology conjures up a repetitive series of fetish images of athletic reality that transforms the body into a competitive and reified fantasy object, a collective hallucination of the national ideal.

Hyper-Critical Theory has in turn been subject to searching criticism by sports scholars, including hegemony theorists of sport like John Hargeaves and Richard Gruneau, for reducing the more open-ended cultural practices of sport to reified structures of economic domination. ${ }^{27}$ For critics, it is an idealist error to erect a totalizing 'sports mode of production' dominating entire nations and continents. Hyper-Critical Theory is contrasted to Adorno's more sophisticated negative dialectic of sport, which retained a utopian aspect in sport's playful promise of a future liberated from instrumental domination. ${ }^{28}$ Others suggest that Adorno was engaged merely in ironic exaggeration as a warning about sport's negative side whereas Hyper-Critical Theory one-sidedly elevates the bad side of sport as a fully adequate description of empirical reality. ${ }^{29}$ If, as Norbert Elias argued, Adorno clung pessimistically to the belated intellectual authority of Marx, then Hyper-Critical Theory hypostatise reductio ad absurdum the inherited authority of theoretical categories from earlier theories, principally Adorno and Marcuse, in place of dynamic social theory adequate to the historical present. ${ }^{30}$

Between the universal critique of sport as unrestrained nationalist violence and UEFA's affirmative promotion of Euro2012 as a brotherhood of nations, figurational sociology contends that football creates and dissipates tensions between reality and fantasy, play and seriousness, restraint and violence in we-images of inter-national figurations. ${ }^{31}$ Rather than a reified object of domination, football engenders historically-specific relations of tension between competing and cooperating groups. To succeed, the internationalisation of football historically required organisational forms at increasing spatial scales of inter-dependency: local, national and transnational. As Norbert Elias classically demonstrated, global sportization was only possible because the state had previously pacified internal space and institutionalised a series of national figurations. ${ }^{32}$ 
Major international football competitions like Euro2012 provide a collective focus for negotiating historical tensions of what Elias called 'group charisma' and 'group disgrace'. ${ }^{33}$ National group charisma depends on routine forms of interdependence and negotiation of boundaries - ethno-cultural, territorial or political - that distinguish 'we' the insiders sharing something in common from 'them' the outsiders who are different in some respect. Dominant nations attribute to themselves all the characteristics of superior virtue and social grace through self-praise and an exemplary image of the 'minority of the best' and impose on dominated nations feelings of 'group disgrace', inferiority and stigma based on 'they-images' of 'the minority of the worst'. At the level of the nation, images of the best in group charisma and the worst in group disgrace also rely on an exemplary 'minority of 11': the national football team. Group charisma is not a once and for all condition. Nations do not stand in a static polarity to each other but actively form relationships of prestige relative to every other nation.

Unlike the categorical declarations of Hyper-Critical Theory, Elias and Dunning revisited the ancient concepts of 'mimesis' and 'catharsis' to more precisely specify the emotional tensions stimulated by football. ${ }^{34}$ For Aristotle artistic productions like tragic theatre should not to be confused with actual human events. Reality is transposed into a different context. In a mimetic context extreme emotions may be safely expressed or vicariously enjoyed in contrast to the more serious business of daily routines. A cathartic effect is produced in competitive football, stimulating and resolving emotional tensions in a pleasurable rather than a destructive way.

Mimetic violence transposes real fears and desires into a protected zone of life. It provides an antidote to dull routine. Against a background of unexciting habits and everyday forms of compulsion football opens up a space for expressing heightened tensions within relatively safe confines, compensatory excitement for "the routinisation of affect', a release of strong emotions through the socially permitted stimulation of competitive tensions within certain boundaries:

One can experience hatred and the desire to kill, defeating opponents and humiliating enemies. One can share making love to the most desirable men 
and women, experience the anxieties of threatened defeat and the open triumph of victory. ${ }^{35}$

What is forbidden is permitted, albeit selectively and under regulatory pressures of social approval. Feelings of national glory are enjoyed and national reversals endured with equanimity, permitting national 'self-love without bad conscience'. ${ }^{36}$

Elias and Dunning situate the cathartic effect of national triumph over vanquished enemies within the shelter of football's fair trial of organised strength. Elias distinguishes between 'achievement sport' of international competitions and more open-ended 'leisure sport'. In the latter case, playful mimesis exerts autonomy from 'real life' tensions; in the former case, achievement threatens to overwhelm playful tensions: 'In the form of achievement sport the playful mimetic tensions of leisure sport becomes dominated and patterned by global tensions and rivalries between different states'. ${ }^{37}$

For the cathartic effect to function, mimetic play creates emotional tensions that fluctuate between opposed waves of anxiety and elation, risk and security. Too little or too much in either direction endangers the effect. Too much control over emotional alternation at the boredom pole and football becomes just another monotonous rulebased regime. Too little control and heightened feelings at the excitement pole may break out into real hostilities of physical violence. Football constantly calibrates between the Scylla of disorder and the Charybdis of boredom. Hence the tone of the game depends on interdependent polarities on the field between teams, attack and defence, within teams, the individual and the team, the referee and the players, and between the field and external controls like spectators, media and traditions of rivalry between teams, fans and nations. As Euronews reported, tensions contingent on the relatively autonomous figuration formed by opposing football teams in competitions like the European Championship will be lost and games made 'meaningless' if results are fixed routinely by criminal organizations attracted by the large fortunes $(31 / 05 / 12)$.

Hyper-Critical Theory rejects figurational sociology's accent on the 'controlled decontrolling' of nationalist emotions: 'in the narrow context of the nation, globalized 
sporting competition no longer helps to contain violence or channel it - as academics such as Norbert Elias and Eric Dunning believe - but rather generates and maintains it, spreading it everywhere'. ${ }^{38}$ In places Brohm asserts that sport serves a cathartic function for capitalism:

As the biggest mass spectacle, sport operates as a kind of catharsis machine, an apparatus for transforming aggressive drives. Instead of expressing themselves in the class struggle, these drives are absorbed, diverted and neutralised in the sporting spectacle. Sport regulates and socialises aggression by providing permitted models of violence. ${ }^{39}$

By foregrounding state formation processes figurational sociology, unlike HyperCritical Theory, tends to relegate the commodification of the sports industry. ${ }^{40}$ This lacuna has been addressed more recently by Eric Dunning, who claims that 'most figurational sociologists would also accept much of what Brohm and Rigauer have to say about the penetration of sport by capital, the concomitant processes of commodification and the permeation of sport by work-like structures' ${ }^{41}$ For others figurational sociology simply defies the demands of scientific falsification. Elastic reasoning about the 'controlled decontrolling' of emotions allows for almost every conceivable outcome in sport, ranging from mass violence (de-civilising breakdown) to self-restraint (civilising controls). ${ }^{42}$ Dunning retorts that such criticism is singularly misplaced. Figurational sociology proposes 'working hypotheses' that remain permanently open to empirical tests of unplanned but patterned historical processes necessary for further theoretical elaboration. ${ }^{43}$

\section{Post-Soviet tensions at the Euros}

The authorised UEFA narrative of 'Creating History Together' attempted to counter the 'tarnished reputation' of post-Soviet authoritarianism and social decay in the eyes of a global audience, especially the European core. Particularly damaging to the weimage of Euro hosts Ukraine and Poland was the charge made repeatedly in European core nations of widespread racism in the European periphery. Post-Soviet nations are allegedly prone to the kinds of violent racism that, it is claimed, was removed decades ago from football stadiums in western Europe. Almost immediately it was reported that black players training with the Netherlands squad were subjected to racist abuse 
in Krakow (08/06/12). Of the nations fined by UEFA for racist fans, two were from the European periphery (Croatia and Russia) while the other, Spain, stands at the pinnacle of world football.

Most attention focussed on post-Soviet fan violence. After their first game, UEFA begun disciplinary proceedings against the Football Union of Russia following fan violence, offensive banners and allegations of racist abuse directed at black Czech defender Theodor Gebre Selassie (10/06/12). Violence was reported at Russia's next game with Poland in Warsaw, leading to around 180 arrests. Euronews put this in the context of the history of state formation: 'Tensions run high when both countries meet at sporting events, given the intense rivalry between the two nations that stretches back centuries. Russia occupied Poland for more than 130 years' (12/06/12). Nationalist tensions were further raised by playing the game on a Russian national holiday. On Euronews the following day the Polish Interior Minister Jacek Cichocki emphasised that foreign fans would be given 'special treatment':

The police investigation is underway and we are fast tracking procedures, especially in the case of foreigners. Within the next two days, by Friday the latest, the football violence thugs, especially Russians, will be sentenced. Those sentenced will be extradited from Poland. (13/06/12, emphasis added)

However, the report also registered the defensive we-images of offended nationalism, with Russia's football authorities blaming fan violence on provocation by Polish fans.

Back in the core, a heightened fear of post-Soviet violence and racism circulated in the UK media. A former English football hooligan interviewed for Sky Sports News Special Report, Ukraine's Hooligans (25/05/12) warned that English fans, now pacified, are burdened with a decades-old reputation for causing mayhem that could see 'the hunter become the hunted' by violent Ukrainian fans. A few days later, a BBC current affairs programme Panorama's Euro 2012: Stadiums of Hate (28/05/12) attracted wider and lasting attention. ${ }^{44}$ It showed football fans in Ukraine making Nazi salutes and violently attacking Asian fans. While the British government advised black English fans to take safety precautions in Ukraine, former England footballer Sol Campbell argued that black fans should stay at home or risk 'coming back in a 
coffin'. Widespread racist violence seemed inevitable at Euro2012 as Hyper-Critical Theory would predict.

While Euronews identified racism and neo-nazis as a problem for post-Soviet football and society, they attempted to balance this with official anti-racism and liberal patriotism of ordinary fans. One bulletin explained how 'passion - for football, their club and country - turns from national pride and patriotism to xenophobia and racism' $(12 / 06 / 12)$. A leader of the fan movement in Lviv admitted that racism exists but that it had been exaggerated by the media, even suggesting that racist violence at football is far worse in the European core:

There is racism at matches. At all matches, whether in Ukraine or elsewhere in the world. There are some displays of it in Lviv as well. One of the reasons for this is that some youngsters confuse nationalism with racism. It's a very thin line which is all too easy to cross. Ukrainian fans mostly limit themselves to hand gestures, but in Europe - France or England - it is much worse, with beatings and killings. We don't have the same level of violence compared with the rest of Europe. (12/06/12)

In the same report, human rights activists complained that Ukraine does not collect official statistics for racially-motivated violence and that the main problem is xenophobic anxiety about strangers rather than racial supremacy: 'sometimes people are hostile. It depends on how cultured they are'. Black South African students in Lviv for the football also rejected the negative characterisation of Ukrainians by the British media and testified to the friendly and safe environment.

For supporters of national teams like England group charisma is more elastic than Hyper-Critical Theory allows. ${ }^{45}$ Euronews showed England fans parading through the streets of Donetsk with a makeshift coffin to make the point that, as paraphrased by the channel's reporter, 'Sol Campbell was out of line and that the Ukraine is not a dangerous country'(19/06/12). England fans were frustrated that media fears about trouble had reduced the size of support willing to travel to Ukraine. As one supporter told Euronews: "We've been on the streets dressed like this [Crusaders]. Nobody has caused us any problems. There has been no racism." (19/06/12). Against images of 
fans and police mixing in the sunshine, the Euronews reporter suggested that only the outcome of the football game itself might sour things: "As you can see, there's no sign of tension or violence so far, as both England and Ukrainian supporters hang out together. But maybe tonight's result will decide whether relations stay so amicable."

\section{A post-Soviet hierarchy of football nations}

In the build-up to Euro2012, Euronews routinely positioned nations in a football hierarchy (see Figure 1). National charisma was adjusted to recent form and past experiences of defeat and victory. Some nations like England and Ukraine selfconsciously lowered expectations while others like Germany and the Czech Republic looked to restore a charismatic position near the top of the football hierarchy, currently occupied by the eventual winners, Spain. Lowest-ranked Poland aimed to simply improve its position and avoid group disgrace. Above all, national teams want to avoid group disgrace by occupying a satisfactory place in the hierarchy corresponding to an idea of national grace even if they cannot win the competition outright.

Figure 1: Position and Prospects for Selected Teams at Euro 2012

\begin{tabular}{|c|c|}
\hline Team & Assessment \\
\hline Croatia & $\begin{array}{l}\text { Since Slaven Bilic's arrival as coach in } 2006 \text { Croatia have not ended } \\
\text { the year outside the top ten in the FIFA World rankings .... Since } \\
\text { their independence the Croats have qualified for the European finals } \\
\text { three times - on two of those occasions, in } 1996 \text { and } 2008 \text {, they } \\
\text { reached the quarter-finals. }(30 / 05 / 12)\end{array}$ \\
\hline Czech Republic & $\begin{array}{l}\text {.. lost to Germany in the Euro } 1996 \text { final and reached the semi- } \\
\text { finals in } 2004 \text {, but since then have slipped down to 26th in the world } \\
\text { rankings and will be eager to re-establish themselves as a force in } \\
\text { European football. }(08 / 06 / 12)\end{array}$ \\
\hline England & $\begin{array}{l}\text { After a disappointing World Cup in South Africa two years ago .... } \\
\text { England's chances at Euro } 2012 \text { have been played down in } \\
\text { comparison to recent tournaments... the only European side to } \\
\text { have won the World Cup but never be crowned European } \\
\text { champions. }(30 / 05 / 12)\end{array}$ \\
\hline Germany & $\begin{array}{l}\text {... a squad looking to end their nation's 16-year-European title } \\
\text { drought. }(06 / 06 / 12)\end{array}$ \\
\hline Greece & $\begin{array}{l}\text { Although they were surprise winners in } 2004 \text {, in the last edition in } \\
\text { Austria and Switzerland, they exited the competition without a point } \\
\text { - an embarrassment they will seek to make amends for on Friday. } \\
(08 / 06 / 12)\end{array}$ \\
\hline Poland & $\begin{array}{l}\text { Poland are the lowest ranked team at the finals but they will still } \\
\text { fancy their chances in group A which, on paper, appears an open }\end{array}$ \\
\hline
\end{tabular}




\begin{tabular}{|l|l|}
\hline Portugal & $\begin{array}{l}\text { contest. (08/06/12) } \\
\text { the only nation out of the four not to have won the European } \\
\text { championship - with Denmark victorious in 1992, Germany a three } \\
\text { times winner }(1972,1980,1996) \text { while the Netherlands lifted the } \\
\text { trophy in 1988. (06/06/12) }\end{array}$ \\
\hline Spain & Reigning World and European champions Spain. (06/06/12) \\
\hline Ukraine & $\begin{array}{l}\text { Coach Oleg Blokhin ... has no illusions about his team's chances. } \\
(30 / 05 / 12)\end{array}$ \\
\hline
\end{tabular}

Here a football hierarchy of nations operates in a perceptual universe at a remove from the geo-political hierarchy of states. As power rivals monopolising the internal organisation of violence, states represent a danger to each other. National groups continue to collectively experience the emotional extremes of national narcissism or national melancholia. If made to feel humiliated and denigrated as inferior nations may be aroused to retaliate against collective disgrace. National disgrace can be experienced personally as a loss of human value in the eyes of the world. A mood of national melancholia may follow from the feeling that present generations are failing the ancestors that once made the nation great, as in the declining football power of England or France. Alternatively, national charisma accompanies the feeling that national honour has been restored by throwing off an oppressor state, as in cases of resurgent nationalisms following the collapse of the Soviet Union, Yugoslavia and Czechoslovakia.

International football may restore to formerly oppressed post-Soviet nations a collective self-image of taking their rightful place as equals in the eyes of the world of nations. At Euro2012 the national shame of fractured post-Soviet self-images created a desire for Ukraine to be seen as a 'normal nation' by the rest of Europe (Euronews, 08/06/12):

"We want to support Euro2012 in Ukraine and to show people from Europe that we are just like they are; that there are no bears walking on the streets of Kyiv but normal and decent people, who are always glad to meet friends and guests who come to visit". 
At the start of the competition an upsurge of national prestige was reported as a consequence of Ukraine becoming the focal point of a global audience: "I am proud of Ukraine because we organised Euro 2012 very well” (02/07/12). Quoting the Mayor of Lviv, Euronews claimed:

Ukrainian people are getting used to a lovely and slightly unusual feeling. The feeling of pride. "Pride. Pride for Lviv. Pride for our native country. It's a special feeling that sends shivers down the spine, when tears appear. And you want so much to have this pride permanently," (26/06/12).

At Euro 2012 the strengthened we-image produced by the globalising figuration appeared to draw Ukrainian nationalism closer to the ideals of European culture, tastes and values. This positive image of Ukrainian hospitality was repeatedly reinforced by Euronews bulletins:

Most foreign fans were pleasantly surprised when they arrived in Ukraine, as the media back home had prepared them for much worse... In the end they're delighted with the country they discovered for themselves. Friendship between Ukrainian and foreign fans can be seen everywhere, and the Euro has not only been a great time for visitors, but for locals as well. (25/06/12)

the festivities and songs in all the different languages are heard throughout streets of the host cities, and the party goes on. (25/06/12)

As one Euro volunteer said, "Euro has opened a new page for Lviv. We have rubbed out the stereotype of the post-Soviet country" (26/06/12).

Official fan-zones and cultural events were organized in public spaces $(08 / 06 / 12){ }^{46}$ In Kiev's fan-zone workshops were held for folk-crafts and local cooking, alongside hours of live music, often performed in English, the global language of commercial culture. One electro-pop band interviewed by Euronews, Gorchitza, declared their mainly English influences 'giving their music a real European feel', and reached for well-worn cultural stereotypes to legitimate collective self-images: "Some say Ukrainians are like the Irish: hot-tempered, explosive, but really kind" (29/05/12). 
'Normal' nations must also possess their own unique 'folk traditions', as the media coordinator of a Ukrainian folk revival festival told Euronews: "It's like Euro 2012's cultural capital. We are trying to combine culture and football and, I think, this is absolutely normal" (22/06/12). One Ukrainian fan added: "Don't think that football fans are just beer-lovers, people who are not interested in culture, who have just one interest - football. We also love world music, we respect our traditions and we're interested in the work of folk artists." (22/06/12).

Group charisma from hosting the competition was transformed into national euphoria when the Ukraine 'minority of 11' unexpectedly beat Sweden in their first game. Euronews put transitory national sporting success in economic and political context: 'an entire nation whose attention has been temporarily diverted from the country's economic problems and political tension' (14/06/12). One Ukrainian summed up the effect: "During the matches, people forget all their troubles. You just worry about the game, about Ukraine, the coach and the players" (15/06/12). Political divisions between ethnic Ukrainians and the large minority of Russian Ukrainians were briefly overcome. As a Ukrainian journalist argued:

"When the Russian team plays, we can see a divide of two countries here, two societies. In Lviv, people will shout 'Hurray! Here it goes!' when the Russian team loses, and in Donetsk, they would celebrate every goal scored by Russia. But when it comes to the Ukrainian team, everyone unites behind them." $(15 / 06 / 12)$.

Such sentiments echo the founding ideology of UEFA as a depoliticised zone of unity, overcoming internal ethnic divisions.

\section{The agony, the ecstasy and the score-draw}

Then Ronaldo struck, prompting jubilation. (22/06/12)

Crowds in Madrid ... saw the fans erupt each time the ball hit the back of the Italian net. $(01 / 07 / 12)$ 
"Wonderful. Unforgettable. Having won like this is wonderful. We deserved even more goals, but it was great anyway." (Italian fan, 29/06/12)

Football not only stimulates cathartic release in an absolute moment of triumph. Pleasure is also taken in the tension and deferral of gratification by the game-contest itself. International football allows for a ritualistic re-enactment of old enmities but also allows for the relief of new tensions. In football, therefore, class resentment or nationalist tensions do not possess the same force of seriousness that they might have in a more directly political or economic context. A demonstration of skill on the football pitch can re-route economic and political tensions between nations in controlled directions, lessening rather than exacerbating the prospects for mass nationalist violence.

"We rather prefer Germany," said one Spanish fan. "It's because technically I think we are better than them. And above all because if Mrs Merkel cuts us off economically, we will cut them off on the pitch." (28/06/12)

Football itself creates tensions and excites violent emotions in socially approved ways. So long as specific limits are observed, fans may indulge in the vicarious experience of collective hatred and the desire to humiliate rivals without breaking out into serious violence. Within football symbolic violence is socially approved, while unrestrained physical violence rarely is.

Even within the limits of the Euronews format an attempt was made to convey something of the tension-balance within games. Reports relied on judgements about technical superiority ('clinical', 'dominated', 'thrash', 'convincing win', 'class', 'precision', etc.) and physical exertion ('determined', 'frustrating', 'effort', 'struggled', 'held on', 'edge out', etc.) (see Figure 2). Some games were dramatic and exciting, tipping towards the excitement pole, while games that were tense, narrow affairs lean towards the boredom pole, as do games that are so one-sided that there is little tension or competition to be enjoyed. In line with most football reporting, Euronews concentrated on moments of high spectacle - the excitement pole individual skill, goals, and dramatic changes in play, but was also compelled to 
represent the boredom pole, for instance in tactically narrow contests where attacking play is largely cancelled out in tense stalemates. Tension is further stimulated by the foresight and calculation demanded by the points format of the competition at the group qualifying stages, followed by the drama of knock-out rounds and penalty shoot-outs, where, at any moment, a mistake or display of skill can prove decisive.

Figure 2: Excitement and boredom in Euronews reports of Euro2012

\begin{tabular}{|c|c|c|}
\hline Date & Result & Report \\
\hline 9 June & Poland 1 Greece 1 & $\begin{array}{l}\text { Lewandowski thrilled the home fans } \\
\text { opening up the scoring } \\
\text { equalizing against the flow of play and } \\
\text { silencing the home crowd }\end{array}$ \\
\hline 9 June & Netherlands v Denmark & $\begin{array}{l}\text { Denmark pulled off the first big surprise } \\
\text { of the tournament with an impressive 1-0 } \\
\text { win over the Netherlands }\end{array}$ \\
\hline 9 June & Russia 4 Czech Republic 1 & The Russian team got off to a flying start \\
\hline 10 June & Germany 1 Poland 0 & $\begin{array}{l}\text { Germany edge out Portugal } \\
\text { a narrow } 1-0 \text { win }\end{array}$ \\
\hline 11 June & Ukraine 2 Sweden 1 & a thrilling 2-1 win \\
\hline 11 June & Croatia 3 Ireland 1 & $\begin{array}{l}\text { Croatia played with class and precision } \\
\text { Slaven Bilic's team played with an } \\
\text { energy and directness }\end{array}$ \\
\hline 11 June & Spain 1 Italy 1 & $\begin{array}{l}\text { tournament favourites Spain were held to } \\
\text { a frustrating 1-1 draw by a determined } \\
\text { Italian side. }\end{array}$ \\
\hline 12 June & Czech Republic 2 Greece 1 & $\begin{array}{l}\text { the } 2004 \text { champions were unable to } \\
\text { salvage a point against a determined } \\
\text { Czech side }\end{array}$ \\
\hline 12 June & Poland 1 Russia 1 & $\begin{array}{l}\text { Group A favourites Russia were held to a } \\
\text { frustrating } 1-1 \text { draw by co-hosts Poland }\end{array}$ \\
\hline $\begin{array}{l}12 \text { June } \\
2102\end{array}$ & Ukraine 2 Sweden 1 & Ukraine's Euro 2012 party started in style \\
\hline 12 June & Portugal 3 Denmark 2 & $\begin{array}{l}\text { In a thrilling ending to the match } \\
\text { Portugal's attacking pressure paid off }\end{array}$ \\
\hline 13 June & Poland 1 Russia 1 & $\begin{array}{l}\text { To the delight of the home fans Poland } \\
\text { had dominated the early exchanges at the } \\
\text { National Stadium. } \\
\text { But on } 37 \text { minutes Polish delight turned } \\
\text { to agony ... } \\
\text { With the hopes of a nation weighing } \\
\text { heavily on their shoulders Poland stepped } \\
\text { it up a notch in the second half - and their } \\
\text { efforts soon paid dividends. }\end{array}$ \\
\hline 14 June & Spain 4 Ireland 0 & $\begin{array}{l}\text { a solid performance for Vicente del } \\
\text { Bosque's men }\end{array}$ \\
\hline 14 June & Italy 1 Croatia 1 & Spain ... started the encounter brightly \\
\hline
\end{tabular}




\begin{tabular}{|c|c|c|}
\hline & & $\begin{array}{l}\text { Croatia refused to sit back and gradually } \\
\text { forced their way back into the tie }\end{array}$ \\
\hline 14 June & Germany 2 Netherlands 1 & $\begin{array}{l}\text { Germany gave the Dutch a lesson in } \\
\text { clinical football }\end{array}$ \\
\hline 16 June & Greece 1 Russia 0 & $\begin{array}{l}2004 \text { champions Greece stunned Group A } \\
\text { favourites Russia } \\
\text { Despite Russia dominating the majority } \\
\text { of play... midfielder Giorgos } \\
\text { Karagounis's first half stoppage-time goal } \\
\text { gave Greece a dramatic and surprise } \\
\text { victory }\end{array}$ \\
\hline 16 June & Czech Republic 1 Poland 0 & $\begin{array}{l}\text { The Czech Republic qualified for the } \\
\text { quarter-finals ... in a dramatic final round } \\
\text { of matches in group A. }\end{array}$ \\
\hline 16 June & England 3 Sweden 2 & $\begin{array}{l}\text { England and their fans breathed a sigh of } \\
\text { relief at Euro } 2012 \text { on Friday night after } \\
\text { they came from behind to beat Sweden 3- } \\
2\end{array}$ \\
\hline 16 June & France 2 Ukraine 0 & the win the French desperately needed \\
\hline 19 June & Italy 2 Ireland 0 & $\begin{array}{l}\text { a convincing } 2-0 \text { win over the Republic of } \\
\text { Ireland }\end{array}$ \\
\hline 19 June & Spain 1 Croatia 0 & $\begin{array}{l}\text { Vicente del Bosque's men dominated } \\
\text { possession and eventually scored the goal } \\
\text { they needed two minutes from time }\end{array}$ \\
\hline 20 June & France 0 Sweden 2 & $\begin{array}{l}\text { Les Bleus missed too many opportunities } \\
\text { in front of goal and conceded an } \\
\text { outstanding second half goal courtesy of } \\
\text { Zlatan Ibrahimovic. }\end{array}$ \\
\hline 20 June & England 1 Ukraine 0 & $\begin{array}{l}\text { Roy Hodgson's men held on to their lead } \\
\text { and just did enough to secure all three } \\
\text { points }\end{array}$ \\
\hline 21 June & $\begin{array}{l}\text { Czech Republic } 0 \text { Portugal } \\
1\end{array}$ & $\begin{array}{l}\text { Portugal dominated, but the Czechs were } \\
\text { kept in the game by several fine saves } \\
\text { from keeper Petr Cech. }\end{array}$ \\
\hline 23 June & Germany 4 Greece 2 & $\begin{array}{l}\text { It was a bit of a frustrating opening half } \\
\text { an hour for the Germans who struggled } \\
\text { with wasteful finishing and sloppy passes. }\end{array}$ \\
\hline 24 June & Spain 2 France 0 & $\begin{array}{l}\text { Jordi Alba brought life to an otherwise } \\
\text { unspectacular game }\end{array}$ \\
\hline 25 June & England 2 Italy 4 (on pens) & $\begin{array}{l}\text { England survived wave after wave of } \\
\text { attack from the Italians, who apart from } \\
\text { the first five minutes of the match } \\
\text { dominated regulation and added time }\end{array}$ \\
\hline 28 June & Italy 2 Germany 1 & $\begin{array}{l}\text { Balotelli shines as Italy beat Germany to } \\
\text { reach final }\end{array}$ \\
\hline 1 July & Spain 4 Italy 0 & $\begin{array}{l}\text { Spain thrash Italy 4-0 to retain European } \\
\text { crown }\end{array}$ \\
\hline
\end{tabular}




\section{Defeat without disgrace}

International football is less 'playful' and more 'serious' than leisure football. The 'best minority of 11' perform a representative function for the self-images of national charisma, more accurately, the wish-image national constructions of sports journalism. At top-level international competitions cathartic resolution is constantly deferred in the face of inevitable setbacks and defeats in the hierarchy of competing football nations. International football is as much, or even more so, the occasion of national anguish within a spoiled mimesis as it is for national self-praise in the cathartic resolution of outright victory.

Every national team, except one (Spain in Euro2012), will lose at some point. National we-images are therefore forced to adjust to the reality of impending defeat. Inter-national football provides training in collective self-restraint at the same time as it excites nationalist emotions. All nations experience defeat on the playing field, moderating, if not eliminating, fantasy images of the national we-group by reality images of the skill, chance, probabilities, tactics, organisation, and so on of rival teams. Even national rivalries established at earlier phases of the state formation process, such as between England and France or Germany and the Netherlands, tend to be resolved with equanimity, more or less, despite contrasting emotions.

There were cheers and shouts of joy from jubilant German football fans, but misery and dejection from supporters of the Netherlands. Germany's 2:1 win in the European Championships against their long term rivals sparked a night of celebration - for some. $(14 / 06 / 12)$

After the opening match ended in a draw, Poles and Greeks leaving the stadium praised each other. As one Greek fan put it, 'the result is fair ... Polish people are very nice people, they are very good people' (09/06/12). Fans were shown as being stoic in defeat, if anything turning inwards for the causes of defeat rather than resenting the victors.

The Scandinavians [Sweden] surprised locals, maintaining a cheerful mood despite losing $2-1$ to the host country. (25/06/12) 
It looks like Netherlands' supporters do not know the meaning of misery. $(25 / 06 / 12)$

"I'm not too sad because the Portuguese team played very well." (Losing Portuguese fan, 28/06/12)

"We're obviously disappointed after the defeat. We would like to have won, but what's most important is the experience of being in Ukraine to support the French national team and that's an unforgettable moment!" (Losing French fan, 24/06/12)

“The Italians played well, we must admit that'. (Losing German fan, 29/06/12)

“The Spanish deserved to win, though not 4-0.” (Losing Italian fan, 02/07/12)

Euronews daily repeated an image of good losers and peaceful contact between fans. Before the final an Italian fan was interviewed: "The Spanish and ourselves are like brothers. In Kiev everything's OK. We say hello to each other, exchange pictures, because after all football is important but it's not the end of the world" (01/07/12). Some fans exemplified their nation's self-image of charismatic conviviality whatever the result:

For football fans visiting Euro 2012, it is not only about what happens on the pitch. It is also a chance to enjoy the festivities around the games. While Irish supporters were stealing the show in Poland, Swedish fans were trying to bring similar joy to Ukraine's capital, Kiev. (25/06/12)

Because it is bound up with collective self-images of nationhood, built-up tensions may not be resolved at the final whistle. As we have noted, players and supporters may still 'go over the score' and transgress the boundaries placed on approved forms of symbolic violence should the national team lose or be disgraced in some way. At Euro2012 this proved something of an exception rather than the rule. 


\section{Conclusion}

For the organisers of international competitions like UEFA, sport potentially represents a depoliticised autonomous field of universal interdependency between nations, where all that matters is the game itself being played within certain limits of approved conduct. From detailed study of Euronews reports, Euro2012 fostered a dynamic, cross-national, post-Soviet figuration rather than simply furthering the interests of commercialised sport and militarism anticipated by Hyper-Critical Theory. ${ }^{47}$ By positing a categorical negation of the official football ideology as universal (particular), civilising (alienating), purifying (corrupting) and elevating (stultifying), Hyper-Critical Theory has effectively abandoned the utopian moment of the repressed desires that football figurations like Euro2012 expresses.

In a context of heightened state rivalries, institutional crisis and national chauvinism across Europe, the incipient violence inherent to the 'sport mode of production' ought to have led to 'unrestrained, generalized violence' at Euro 2012 predicted by HyperCritical Theory. There was no generalised violence. The behaviour of players, officials and spectators was generally restrained, despite reports of some episodes of nationalist and racist abuse and fighting between rival fans. Instead of focussing on exceptional moments of unrestrained violence what needs explained instead is the routine collective and personal control over fluctuating emotional tensions at football matches. ${ }^{48}$ Euro2012 functioned generally as a 'symbolic representation of nonviolent, non-military competition between states' ${ }^{49}$ Although a number of violent incidents were reported at Euro2012 by Euronews, the formal threshold for on-field violence has been raised to a historically high level. An illustration of this is that the number of cautions and dismissals at Euro 2012 remained at the historically low level of Euro 2008. Football effects a temporary release from self-restraint, 'a controlled decontrolling of restraint' not possible in other spheres of daily life. Here the seriousness of international football competitions suggests a converging tendency of 'sportization' between nations.

Outside of wartime, competitions like Euro 2012 offer one of the few venues for group charisma of post-Soviet nations to find a global public at a definite, crisisridden phase in the state formation process. Even now, in the depths of decay and 
crisis, this does not always demand victory at all costs. Rather the development of national charisma establishes self-images of the 'national game', where it is understood that certain, albeit changeable practices of fans or players demean or shame the nation in the eyes of a global football public, while other practices earn respect and recognition. No social group, players, officials, media or fans, is able to disregard entirely the field capabilities of the 'best minority of 11 ' engaged in the serious game of exemplifying group charisma.

\section{References}

Adorno, Theodor W. 'Veblen's attack on culture'. In Prisms. Cambridge, MA: MIT Press, 1967.

Billig, Michael. Banal Nationalism. London: Sage.

Brohm, Jean-Marie. Sport: A Prison of Measured Time, London: Pluto Press, 1978.

Crolley, L., D. Hand, and R. Jeutter. 'Playing the Identity Card: Stereotypes in European Football'. Soccer \& Society 1 (2000): 107-28.

Dunning, Eric. 'Figurational sociology and the sociology of sport: Some concluding remarks'. In Sport and Leisure in the Civilizing Process: Critique and Counter-Critique. Edited by E. Dunning and C. Rojek, 221-284. Basingstoke: Macmillan, 1992.

Dunning, Eric. Sport Matters: Sociological Studies of Sport, Violence and Civilization. London: Routledge, 1999.

Elias, Norbert and Eric Dunning, 'Leisure in the spare-time spectrum'. Quest for Excitement: Sport and Leisure in the Civilizing Process. Oxford: Basil Blackwell, 1986.

Elias, Norbert and Eric Dunning, Quest for Excitement: Sport and Leisure in the Civilizing Process. Oxford: Basil Blackwell, 1986.

Elias, Norbert, 'A theoretical essay on established and outsider relations'. Norbert Elias and John L. Scotston, The Established and the Outsiders, London: Sage, 1994.

Elias, Norbert, 'Group charisma and group disgrace'. In Collected Works, Volume 16, eds. R. Kilminster and S. Mennell, 73-81. Dublin: University College Dublin Press, 2009. 
Elias, Norbert. 'An essay on sport and violence'. Quest for Excitement: Sport and Leisure in the Civilizing Process. Oxford: Basil Blackwell, 1986.

Elias, Norbert. 'Football in the process of civilisation', In Collected Works, Volume 16, eds. R. Kilminster and S. Mennell, 190-197. Dublin: University College Dublin Press, 2009.

Elias, Norbert. 'Processes of state formation and nation-building'. Collected Works, Volume 15, eds. R. Kilminster and S. Mennell, 105-118. Dublin: University College Dublin Press, 2008.

Elias, Norbert. 'Address on Adorno: Respect and critique'. In Collected Works, Volume 16, eds. R. Kilminster and S. Mennell, 82-91. Dublin: University College Dublin Press, 2009.

Elliot, Larry. and Decca Aitkenhead. 'It's payback time: don't expect sympathy Lagarde to Greeks', The Guardian, 25 May 2012.

Euro 2012. Regulations of the UEFA European Football Championship, 2010-12. 2009.

http://www.uefa.com/MultimediaFiles/Download/Regulations/competitions/R egulations/91/48/36/914836_DOWNLOAD.pdf.

Garcia-Blanco, Inaki, and Stephen Cushion. 'A partial Europe without citizens or EUlevel political institutions'. Journalism Studies 11 (2010): 393-411.

Gibbons, Tom. 'English national identity and the national football team: the view of contemporary English fans'. Soccer \& Society 12, no. 6 (2011): 865-879.

Giulianotti, Richard, 'Civilizing games: Norbert Elias and the sociology of sport'. In Sport and Modern Social Theorists, ed. R. Giulianotti, 145-160. Basingstoke: Palgrave Macmillan, 2004.

Goldblatt, David. The Ball is Round: A Global History of Football. London: Penguin, 2007.

Gripsrud, Jorstein. 'Television and the European public sphere'. European Journal of Communications 22 (2007): 479-92.

Hargreaves, John. Sport, Power and Culture. Oxford: Polity Press.

Inglis, David. 'Theodor Adorno on sport: The jeu d'esprit of despair'. In Sport and Modern Social Theorists, ed. R. Giulianotti, 81-96. Basingstoke: Palgrave Macmillan, 2004.

Gruneau, Richard. 'The critique of sport in modernity: Theorising power, culture and the politics of the body'. In The Sports Process: A Comparative and Developmental Approach. Edited by Eric G. Dunning, Joseph A. Maguire and Robert E. Pearton. Champaign, IL.: Human Kinetics (1993): 85-110. 
Inthorn, Sanna. 'Europe divided, or Europe united? German and British press coverage of the 2008 European Championship' Soccer \& Society 11, no. 6 (2010):790-802;

Kaptyken, Paul. The Stateless Market: The European Dilemma of Integration and Civilization . London: Routledge, 1996.

King, Anthony. 'Football Fandom and Post-National Identity in the New Europe'. British Journal of Sociology 51 (2000): 419-42.

Lauss Georg and András Szigetvari. 'Governing by fun: EURO 2008 and the appealing power of fan zones'. Soccer \& Society 11, no.6 (2010): 737-747.

Liston, Kate. 'Sport and leisure'. In Norbert Elias and Figurational Research: Processual Thinking in Sociology, eds. N. Gabriel and S. Mennell, 160-180. Oxford: Wiley-Blackwell/The Sociological Review, 2011.

Maguire, Joseph and Emma Poulton. 'European Identity Politics in Euro 96: Invented Traditions and National Habitus Codes'. International Review for the Sociology of Sport 34 (1999): 17-29.

Manzenreiter, Wolfram and Georg Spitaler. 'Governance, citizenship and the new European Football Championships: the European spectacle'. Soccer \& Society 11, no. 6 (2010): 695-708.

Mittag, Jürgen and Benjamin Legrand. 'Towards a Europeanization of Football: Historical phases in the evolution of the UEFA European Football Championship'. Soccer \& Society 11, no. 6 (2010): 709-722.

Morrissey, Sean. 'Un homme avant tout': Zinedine Zidane and the sociology of a head-butt'. Soccer \& Society10, no. 2 (2009): 210-225.

Perelman, Marc. Barbaric Sport: A Global Plague. London: Verso, 2012.

Poulton, Emma. 'Mediated Patriot Games: The Construction and Representation of National Identities in the British Television Production of Euro '96'. International Review for the Sociology of Sport 39 (2004): 437-55.

Rigauer, Bero. Sport and Work, New York : Columbia University Press, 1981

Smith, Dennis. Globalization: The Hidden Agenda. Cambridge: Polity Press, 2006.

Wiggerhaus, Rolf. The Frankfurt School: Its History, Theory and Political Significance. Cambridge: Polity, 1995.

Morgan, William J. 'Adorno on sport: The case of the fractured dialectic', Theory and Society, 1988. 17.6: 818-38.

Morgan, William J. Leftist Theories of Sport: A Critique and Reconstruction: Champaign, IL, University of Illinois Press. 
Zolberg, Vera. 'Elias and Dunning's theory of sport and excitement'. Theory, Culture and Society 4, nos. 2-3 (1987): 571-5.

${ }^{1}$ I would like to acknowledge the critical insight and helpful suggestions of Christos Memos and Peter Kennedy on an earlier version of this paper.

${ }^{2}$ http://www.uefa.com/uefaeuro/abouteuro/organisation/logobrand/index.html

${ }^{3}$ Smith, Globalization.

${ }^{4}$ Just weeks before Euro2012 Jürgen Fitschen, joint head of Germany's biggest bank, Deutsche, reportedly described Greece as "a failed state ... a corrupt state'. In an interview with the Guardian newspaper, Christine Lagarde, Managing Director of the IMF, was reported as having more sympathy for victims of poverty in sub-Saharan Africa than Greeks hit by the economic crisis. Elliot and Aitkenhead, 'It's payback time'.

${ }^{5}$ Mittag and Benjamin, 'Towards a Europeanization of Football', 720.

${ }^{6}$ Inthorn, 'Europe divided, or Europe united?'; Crolley, Hand and Jeutter. 'Playing the Identity Card'; King, 'Football Fandom and Post-National Identity in the New Europe'; Maguire, and Poulton. 'European Identity Politics in Euro 96'; Poulton, 'Mediated Patriot Games'.

${ }^{7}$ Kaptyken, The Stateless Market, 142.

${ }^{8}$ Morrissey, 'Un homme avant tout'.

${ }^{9}$ The eleven languages are: Arabic, English, French, German, Italian, Persian, Portuguese, Russian, Spanish, Turkish, and Ukrainian.

${ }^{10}$ Gripsrud, 'Television and the European public sphere'.

${ }^{11}$ Garcia-Blanco and Cushion, 'A partial Europe without citizens or EU-level political institutions'.

${ }^{12}$ Billig, Banal Nationalism.

13 'EURO 2012'TM broadcasting deal agreed with EBU', 23 September 2009, http://www.uefa.com/uefa/mediaservices $/$ mediareleases/newsid=941165.html

${ }^{14}$ The European Championship alternates with FIFA's World Cup for a share of the global sports-media audience. Even more nations will participate as the competition expands from 16 to 24 teams for Euro 2016 in France. Plans for multiple host countries across Europe for Euro 2020 met early opposition in a survey of fans. See James Riach, 'Fans reject Michel Platini's 'zany' plan for continent-wide Euro 2020', The Guardian, 7 December 2012.

${ }^{15}$ Euro 2012, Regulations of the UEFA European Football Championship, 49.

${ }^{16}$ Ibid. 51.

${ }^{17}$ Ibid. 51.

${ }^{18}$ Ibid. 52, emphasis added.

${ }^{19}$ Wiggerhaus, Rolf, The Frankfurt School.

${ }^{20}$ Adorno, 'Veblen's attack on culture', 81.

${ }^{21}$ Rigauer, Sport and Work.

${ }^{22}$ Perelman, Barbaric Sport, 48.

${ }^{23}$ Perelman, Barbaric Sport, 43.

${ }^{24}$ Perelman, Barbaric Sport, 33, emphasis added. 
${ }^{25}$ Ibid. 22.

${ }^{26}$ Brohm, Sport, A Prison of Measured Time, 15.

${ }^{27}$ Hargreaves, Sport, Power and Culture; Gruneau, 'The critique of sport in modernity'.

${ }^{28}$ Morgan, Adorno on sport'. For a liberal reconstruction of Critical Theory of sport see Morgan, Leftist Theories of Sport.

${ }^{29}$ Inglis, 'Theodor Adorno on sport'.

${ }^{30}$ Elias, 'Address on Adorno'.

${ }^{31}$ Elias and Dunning, Quest for Excitement. For a survey of figurational studies and debates in the sociology of sport see Liston, 'Sport and leisure'.

${ }^{32}$ Elias, 'An essay on sport and violence'. For a global sociological history of football see Goldblatt, The Ball is Round.

${ }^{33}$ Elias, Norbert, 'Group charisma and group disgrace'; Elias, 'A theoretical essay on established and outsider relations'.

${ }^{34}$ Elias and Dunning, 'Dynamics of sport groups with special references to football, 200-203; Elias, Introduction, Note 11, 287-9.

${ }^{35}$ Elias and Dunning, 'Leisure in the spare-time spectrum', 125.

${ }^{36}$ Elias, Introduction, Note 11, 289.

${ }^{37}$ Elias, 'Introduction', 44.

${ }^{38}$ Perelman, Barbaric Sport, 34.

${ }^{39}$ Brohm, Sport, A Prison of Measured Time, 180.

${ }^{40}$ Zolberg, 'Elias and Dunning's theory of sport and excitement'.

${ }^{41}$ Dunning, Sport Matters, 111.

42 Giulianotti, 'Civilizing games'.

${ }^{43}$ Dunning, 'Figurational sociology and the sociology of sport'.

${ }^{44} \mathrm{http}: / /$ www.bbc.co.uk/news/uk-18192375

${ }^{45}$ Gibbons, 'English national identity and the national football team'.

${ }^{46}$ Lauss and Szigetvari, 'Governing by fun'.

${ }^{47}$ Manzenreiter and Spitaler, 'Governance, citizenship and the new European Football Championships'.

${ }^{48}$ Elias, 'Football in the process of civilisation'.

${ }^{49}$ Elias, 'Introduction', 23. 